Person-Centred Therapy 


\section{Person-Centred Therapy}

\section{The Focusing-Oriented Approach}

CAMPBELL PURTON 


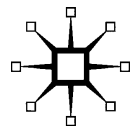

(c) Campbell Purton 2004

All rights reserved. No reproduction, copy or transmission of this publication may be made without written permission.

No paragraph of this publication may be reproduced, copied or transmitted save with written permission or in accordance with the provisions of the Copyright, Designs and Patents Act 1988, or under the terms of any licence permitting limited copying issued by the Copyright Licensing Agency, 90 Tottenham Court Road, London W1T 4LP.

Any person who does any unauthorised act in relation to this publication may be liable to criminal prosecution and civil claims for damages.

The author has asserted his right to be identified

as the author of this work in accordance with the Copyright,

Designs and Patents Act 1988.

First published 2004 by

PALGRAVE MACMILLAN

Houndmills, Basingstoke, Hampshire RG21 6XS and

175 Fifth Avenue, New York, N.Y. 10010

Companies and representatives throughout the world

PALGRAVE MACMILLAN is the global academic imprint of the Palgrave

Macmillan division of St. Martin's Press, LLC and of Palgrave Macmillan Ltd. Macmillan ${ }^{\circledR}$ is a registered trademark in the United States, United Kingdom and other countries. Palgrave is a registered trademark in the European Union and other countries.

\section{ISBN 978-0-333-96916-8 ISBN 978-0-230-21456-9 (eBook)}

DOI 10.1007/978-0-230-21456-9

This book is printed on paper suitable for recycling and made from fully managed and sustained forest sources.

A catalogue record for this book is available from the British Library.

A catalog record for this book is available from the Library of Congress.

$\begin{array}{rrrrrrrrrr}10 & 9 & 8 & 7 & 6 & 5 & 4 & 3 & 2 & 1 \\ 13 & 12 & 11 & 10 & 09 & 08 & 07 & 06 & 05 & 04\end{array}$


For Val, Dinah and Tom 


\section{Contents}

Acknowledgements viii

Terminological Note $\quad \mathrm{x}$

Introduction 1

1. Rogers and the Development of Person-Centred Therapy 11

2. Fault-Lines in Person-Centred Theory 31

3. The Origins of Focusing 54

4. Focusing as a Taught Procedure $\quad 82$

5. Focusing-Oriented Psychotherapy 96

6. Objections: Issues of Principle and Empirical Issues 143

7. Training and Supervision 163

8. Towards a Theory of Psychotherapy 175

$\begin{array}{ll}\text { Conclusion } & 207\end{array}$

Appendix A: The Wider Context 210

Appendix B: Resources 236

References $\quad 237$

$\begin{array}{ll}\text { Index } & 250\end{array}$ 


\section{Acknowledgements}

I would like to thank Yoshihiko Morotomi for drawing my attention to the work of Fujio Tomoda. It was from that spark that my interest in focusing developed. Barbara McGavin was my first Focusing teacher, followed later by Rob Foxcroft. I owe much to both of them. My understanding of focusing has also been helped by attendance at Eugene Gendlin's 'Thinking at the Edge' workshop in New York, and by workshops run by Maarten Aalberse and Kevin McEvenue.

I am grateful to Rose Battye, Paul Cassell, Ann Weiser Cornell, Sarah Hawtin, Dave Mearns, Judy Moore and two anonymous publishers' readers, who kindly read and commented on parts of, or drafts of, the book. They have helped to make the book better than it would otherwise have been. I would also like to thank my Palgrave editors Alison Caunt and Andrew McAleer for their patient support during the writing of the book.

The 'Focusing and the Power of Philosophy' courses, on the Isle of Cumbrae, which I have taught with Rob Foxcroft, Barbara McGavin and Kye Nelson, helped a lot in clarifying my own understanding of Gendlin's thinking. I benefited from the opportunity to discuss parts of the book - over wine and cake - at the UEA Counselling Service 'Writing and Research Group'; also from teaching focusing on the UEA counselling diploma course. I have learned a lot from our trainees, and I have very much valued the support of my colleagues, Caroline Brown, Ian Draper, Judy Moore, Eamonn O'Mahony and Louise Young, on the course.

My understanding of focusing has been helped greatly by my counselling clients; I hope that they have benefited as much from my involvement in focusing as I have from working with them.

I am grateful to Brian Thorne, with whom I have worked for so many years, for his initial encouragement to write the book and for his continuing interest in it; to Muriel Frankl, who helped me see that focusing, in spite of its being a way of helping people find their own path, can get in the way of precisely that; to Mary Hendricks, indefatigable Director of the Focusing Institute, for all her help along the way; and to Gene Gendlin himself. Gendlin has not read this book, though we have had helpful email discussions about some of 
the material. I am sure that in some places I will have unintentionally misrepresented his ideas, and I apologise to him in advance for that. I will have to leave it to the reader to assess how well I have done in this regard, after they have consulted Gendlin's own writings. I very much hope that readers will do this.

My daughter Dinah (now working on a $\mathrm{PhD}$ on existential themes) and my son Tom (now completing a Masters degree in psychoanalysis) have helped to make me feel that it is all worthwhile. Finally, my thanks to $\mathrm{Val}$, who shares with me the pains and pleasures of trying to write in spite of the pressures of our over-busy lives. 


\section{Terminological Note}

I have for the most part chosen to use the pronouns 'they', 'them', 'their' and 'themself' as singular forms in place of the gender-specific 'he', 'him', and 'his' and 'himself'. This is because I find that the consistent use of 'he or she', 'him or her' and so on often leads to impossibly contorted sentences (how, for example, could one live with such a rendering of 'He himself might feel that he would like his work to be more congenial to him'?). 'S/he' is unpronounceable, and the device of alternating the use of feminine and masculine pronouns runs into difficulties in contexts where gender-specific pronouns are required, and the distinction between a gender-specific 'him' and a gender-neutral 'him' is lost. There can be awkwardnesses in the singular use of the grammatically plural forms; for example, I have preferred forms such as 'while they themself think' to the grammatically correct 'while they themselves think' (though my word-processor keeps 'correcting' this); however, I find I can live with these awkwardnesses more comfortably than with any of the alternative ways around the problem. Singular uses of grammatical plurals are not unknown, although some readers may echo Queen Victoria's apocryphal 'We are not amused'. 